\title{
Audiovisual Material
}

National Cancer Institute

\section{Source}

National Cancer Institute. Audiovisual Material. NCI Thesaurus. Code C19695.

Materials using sight or sound to present information. 